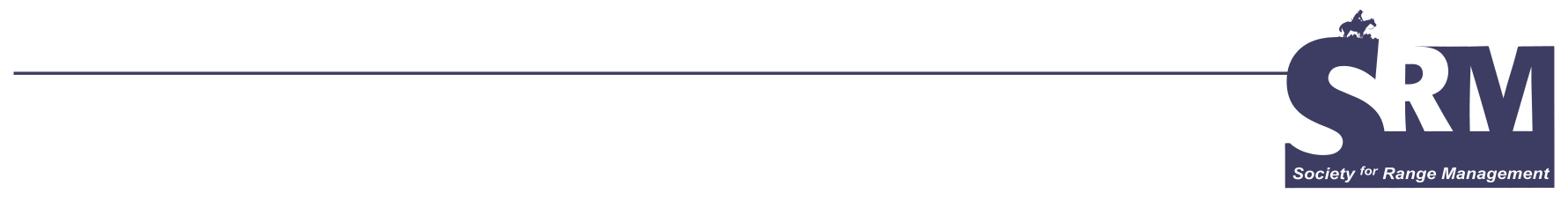

\title{
Crisis Management: Challenge and Controversy in Forest Service History
}

\section{By Char Miller}

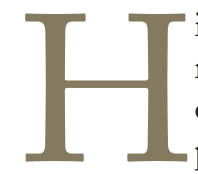

istory is the language we employ to describe our relationship to the past. It is how we speak to ourselves about previous generations, their lives, perspectives, achievements, failures; but it is also a form of communication the present uses to talk to itself about itself. History, in that sense, allows us to assess our heritage and inheritance. ${ }^{1}$

This reciprocal dialog is as evident in studies of individual lives (biography) and assessments of family constellations (psychology) as it is in analyses of social organizations (sociology), and, in truth, because individuals emerging out of familial environments make up the social organisms in which humans live, learn, work, and play, this kind of evaluative discourse cannot help but be multilayered.

And very complicated. Take, for instance, the USDA Forest Service, which in 2005 is celebrating its centennial. How do you track its history? Which language or set of terms best captures its evolution over time? What determines that which it has bequeathed to its employees and the broader public it has served for so long in different eras? (Not to mention its effect on the land under its care.) To address some of these questions, I want to reframe them through a discussion of 4 key challenges that Forest Service leadership has had to confront over the past 100 years.

\section{How Do You Create an Agency?}

That query defined everything that Gifford Pinchot and the first leadership team pursued. In 1898, Pinchot became the 4th head of the division of forestry in the Department of Agriculture and immediately began to plan for the creation of what would become the Forest Service. The first task was to build public support for what was in fact a rad- ical idea-creating a land management agency that would regulate the public domain. Hitherto, the public lands west of the Mississippi had been given away, sold cheaply, or lost because of fraud; this privatization was politically acceptable because the stated ambition was that these lands would build frontier communities. But the environmental costs of these land transfers-totaling 1 billion acres-particularly those involving timber and livestock production, mounted across the late 19th century. Fears of a timber famine and dust bowl rangeland conditions, along with a growing conviction that federal intervention through conservation management might rehabilitate battered landscapes, generated pressure on Congress to act. In 1876, it created the small division that Pinchot would inherit 20 years later; in 1891, it established the first forest reserves, and between then and 1897, Presidents Benjamin Harrison and Grover Cleveland added nearly 40 million acres to the reserves; in 1897, a rider attached to an appropriations bill, now called the Organic Act, defined how those new reserves were to be managed.

To capitalize on these initiatives, Pinchot and his staff moved in two directions simultaneously: Without forests to work on-the reserves were located in the Interior Department, and the nation's foresters were in Agriculturethe agency issued Circular 21, offering their professional services to landowners large and small. This would give its agents an opportunity to field test their ideas and secure favorable publicity. They also launched a quiet campaign to transfer the national forests to their care, which received a huge boost in 1901 when Theodore Roosevelt succeeded the assassinated President McKinley. Four years later, the transfer was complete, and the Forest Service was born. 


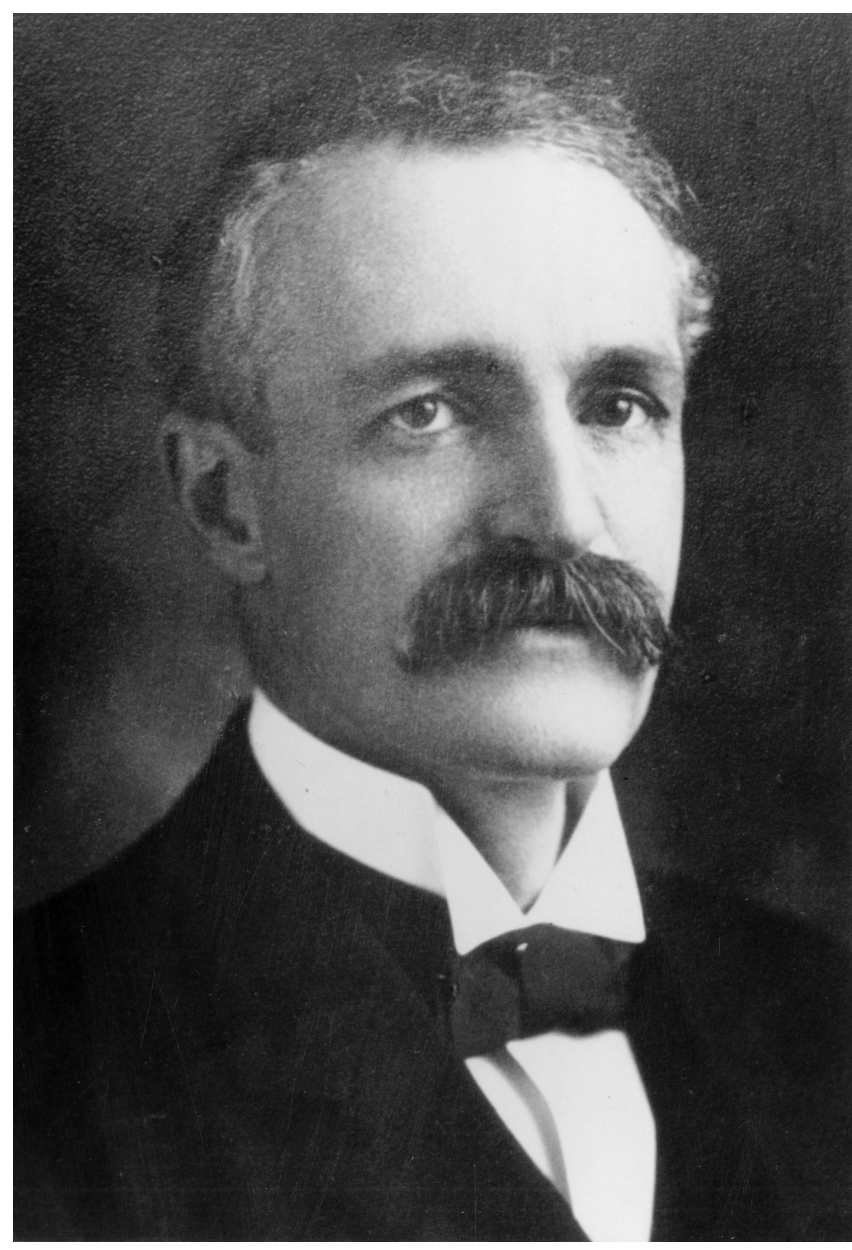

Gifford Pinchot was not only the first Chief of the Forest Service, he is also known for establishing the Society of American Foresters. Photo courtesy of U.S. Forest Service.

That was the easy part. With Roosevelt adding upward of 150 million acres to the national forest system, Forest Service leadership had to construct a multitiered bureaucracy, hire employees at all levels, and commence to survey, manage, and provide minimal fire protection for these lands. They also developed research stations and nurseries to aid its scientific analysis and regeneration of abused terrain. Pinchot and his peers were up to the task. To create a workforce, the Pinchot family donated more than $\$ 250,000$ to create the Yale School of Forestry (1900), and built a summer training camp on family lands in Milford, Pennsylvania. That same year, Pinchot established The Society of American Foresters and the Journal of Forestry, critical markers of professionalization. To further denote foresters' expertise, staff designed a quasi-military uniform, issued the "Use Book" (1905) that described rangers' daily work and authority, and developed a code of ethics, dubbed "Rules for Public Service," to oversee the managers' behavior. Most crucially, to establish precedence for its regulatory power, the agency sued violators in federal court, each of which the Supreme Court resolved in its favor. ${ }^{2}$ By 1910, the Forest Service served as a harbinger, novelist Hamlin Garland assured readers of Cavanagh, Forest Ranger, of the new nation state, a much-needed civilizing force in the rough-and-tumble West. ${ }^{3}$

Naturally, that was the year Pinchot conspired to be fired for insubordination. After William $\mathrm{H}$. Taft had replaced Roosevelt in 1908, the new president and the forester repeatedly clashed because, in Pinchot's mind, Taft did not share the Roosevelt/Pinchot passion for extending executive branch power or their devotion to conservationism. News of suspicious coal field leases in Alaska led Pinchot publicly to confront the administration, which provoked his dismissal. In this, he had practiced as he had preached: the last advisory in "Rules for Public Service" was: "Don't make enemies unnecessarily and for trivial reasons; if you are any good you will make plenty of them on straight honesty and public policy ...."

\section{How Do You Redefine an Agency's Mission?}

Pinchot's shrewd insight and brave words nonetheless left his successors in a bind. Henry Graves, whose European forestry training Pinchot had underwritten, and who had served as his Associate Forester before becoming Dean at the Pinchot-funded Yale School of Forestry, became the second chief. Because he had so long labored in his close friend's shadow, it made sense that he take up the reins. Less provocative and less charismatic than his friend, Graves knew his mission was to rebuild internal morale, reknit the agency's frayed relations with the White House and Congress, and reclaim public confidence. None of that came easily and yet, however hindered by sharp budget cuts and congressional hostility, Graves managed to stabilize the agency, smoothing the way for William B. Greeley to become its 3rd chief in 1920 .

Unlike Graves, Greeley immediately picked a series of fights with Pinchot, challenging his still-profound influence in the Forest Service. Only in this way, Greeley believed, could he reform the organization in his own image. More conservative than the founder and more comfortable with the corporate Republicanism dominating the political arena in the 1920s, Greeley promoted cooperative relationships with the timber and grazing industries. He countered Pinchot's faith in rigorous regulation by advocating through the Clarke-McNary Act (1924) an accommodation of powerful interest groups. On the matter of federal authority on the national forests, which Pinchot championed and hoped to extend to private lands, Greeley blasted this notion as "unAmerican." ${ }^{4}$ Years earlier, Greeley had been thrilled to have "lost caste in the temple of conservation on Rhode Island Avenue," a sneering reference to Pinchot's Washington, DC, manse, and he did little to repair their relationship while chief (p. 282). ${ }^{5}$ His perspectives on the agency's political purpose, social significance, and economic agenda so dominated professional forestry in the 1920s that an embittered Pinchot resigned from the American Forest Association and stopped attending Society of American Foresters meetings. 


\section{Rules for Public Service}

1. A public official is there to serve the public and not run them.

2. Public support of acts affecting public rights is absolutely required.

3. It is more trouble to consult the public than to ignore them, but that is what you are hired for.

4. Find out in advance what the public will stand for; if it is right and they won't stand for it, postpone action and educate them.

5. Use the press first, last, and all the time if you want to reach the public.

6. Get rid of the attitude of personal arrogance or pride of attainment or superior knowledge.

7. Don't try any sly or foxy politics because a forester is not a politician.

8. Learn tact simply by being absolutely honest and sincere, and by learning to recognize the point of view of the other man and meet him with arguments he will understand.

9. Don't be afraid to give credit to someone else even when it belongs to you; not to do so is the mark of a weak man, but to do so is the hardest lesson to learn; encourage others to do things; you may accomplish many things through others that you can't get done on your single initiative. 10. Don't be a knocker; use persuasion rather than force, when possible; plenty of knockers are to be had; your job is to promote unity.

11. Don't make enemies unnecessarily and for trivial reasons; if you are any good you will make plenty of them on matters of straight honesty and public policy and will need all the support you can get.

Greeley was much less nimble in his response to a more serious bureaucratic threat posed by an aggressive National Parks Service (NPS). Founded in 1916, and headed by former advertising executive Stephen Mather, the NPS quickly came into its own at the expense of the Forest Service. Proclaiming its mission to serve the recreational needs of the car-crazy culture, NPS moved rapidly to publicize the national parks, develop highway connections between them, and gain public (and therefore congressional) support for its appropriation of national monuments and majestic parklands - then under Forest Service control. So effective were Mather and his managers, and so flat-footed did their Forest Service peers appear, that they plucked one gem after another out of the national forest inventory.

In taping "the pulse of the Jazz Age," historian Hal Rothman has observed, NPS sold "Americans leisure and grandeur at a time when ... outdoor recreation increased," an understanding of contemporary needs the Forest Service failed to appreciate. ${ }^{6}$ Although individual employees, such as Arthur Carhart, Aldo Leopold, and Bob Marshall, pushed the Forest Service to establish wilderness and backcountry recreation, in general, the agency's goals in the newly competitive environment seemed "undefined and utterly up in the air." Once proactive, the Forest Service had become reactive, a sign of lost momentum.

\section{How Do You Protect the Agency's Existence?}

The Great Depression, ironically enough, offered an opportunity for the agency to make up lost ground. Greeley had resigned in 1928, becoming secretary of the West Coast Lumberman's Association-proof of his real allegiances, Pinchot averred. His replacement, Robert Y. Stuart, a Pinchot ally, was chief until 1933, dying in a tragic fall from his Washington office window. Ferdinand Silcox then navigated the agency through the harrowing and hard times, proving an adept administrator. Taking full advantage of a large influx of federal dollars flowing through the Civilian Conservation Corps, among other New Deal funding mechanisms, the Silcox-led organization began to purchase abandoned and abused lands in the South, Middle West, and Great Plains; these new forests and grasslands became employment opportunities for CCC enrollees, who planted seedlings, built shelter belts, repaired eroded terrain, and constructed cabins and trails. The can-do agency was at the top of its game.

Only to be thrown a curve-ball. In the early 1930s, Interior Secretary Harold Ickes pressed President Franklin Roosevelt to support the creation of a new cabinet-level
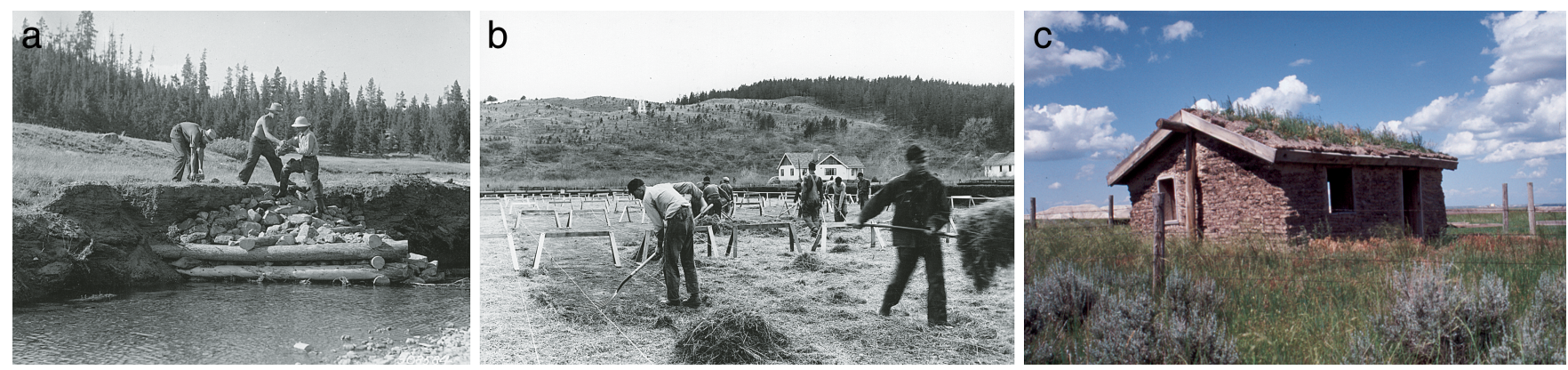

The Civilian Conservation Corps worked on many forest and rangeland restoration practices in the 1930s. During the same period, abandoned farms that were later to become the Forest Service National Grasslands were being purchased by the Federal government. Photos courtesy of U.S. Forest Service. 
Department of Conservation that would absorb all federal land management agencies, especially the Forest Service. Convinced that efficiencies would result, the president approved the plan, muzzled the Secretary of Agriculture, Henry Wallace, and had him prevent the Forest Service from defending itself. In need of allies, Silcox, through Associate Chief Earl Clapp, contacted Gifford Pinchot, then 70, to champion the agency's cause. He did. Between 1935 and 1940, Pinchot and Ickes engaged in one of the most bruising bureaucratic brawls in modern American political history. Over the radio, in newspapers and magazines, and from one podium to another, they pounded each other while rallying their supporters to fight for or against the transfer. In the end, Pinchot triumphed, a remarkable testament to his skilled in-fighting and dogged perseverance. ${ }^{5}$

His victory was not unalloyed. There was a personal cost for at least one high-ranking forester who had cooperated with the old chief's activities. The president never promoted Earl Clapp beyond "acting chief," a position he had assumed following Silcox' death in 1939, because he was convinced that Clapp had orchestrated the stout resistance to Ickes' transfer scheme. In sacrificing his career for what he conceived to be the greater good, Clapp paid a heavy professional price. The same might be said about the Forest Service itself. In its fierce fight for survival, it might have missed an important opportunity to engage in a serious consideration of how conservationism was evolving and how it would be implemented in the coming years; it also failed to reflect on the governmental structure best suited to conserve the lands under its care. As it entered the war years, the agency was intact and independent, but it was also insular in orientation, a quality that would complicate its ability to react to the massive changes that would come in post-war America.

\section{How Do You Ensure the Agency's Continued Relevance?}

Those unique pressures came in a rush. Returning soldiers married by the millions, generating a baby boom of immense proportions. This demographic surge, and the housing demand it produced, dovetailed with a shift in the source of timber for the lumber industry. With private supplies largely tapped out as a result of the depression and World War II, public forests were brought into production, and swiftly so. Harvesting during the agency's first 40 years had not topped 2 billion board feet (BBF) per annum. Beginning in the 1950s, timber harvest figures climbed sharply, peaking at more than 12 BBF by the late 1980s. Getting out the cut was now the Forest Service's mission, and it shaped its internal culture, too: A large number of silvicultural specialists and engineers were hired and promoted into leadership positions. Formed in response to late 19th century anxieties about woodland devastation, 50 years later the agency, once a custodial outfit, had pushed to the front lines of hard hat-wearing timber productivity. ${ }^{8}$

To accelerate the amount of sawlogs heading to mills, it

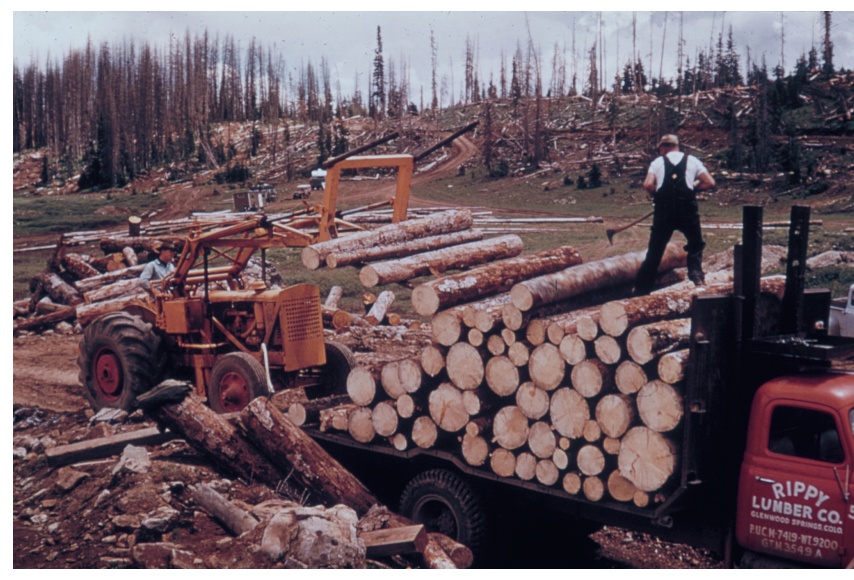

Following WWII, the Forest Service began to place increasing emphasis on timber harvest, peaking at more than $12 \mathrm{BBF}$ in the 1980s. National Forest timber harvests have declined by $84 \%$ between 1986 and 2001 and now account for only 2\% of timber harvested in the United States (Forest Resources of the United States, 2002, by W. B. Smith et al., GTRNC-211). Photo courtesy of U.S. Forest Service.

instituted clear-cutting on the national forests, a technique that met production targets but damaged sensitive ecosystems and shocked the very suburbanites who lived in the subdivisions built from this wood. As they headed out to these forests on their summer vacations, the homeowners were confronted with the consequences of their consumptionstripped terrain where once trees soared, scoured riparian systems where once they had fished, debris-littered open spaces where they had once hunted. If they had also read Aldo Leopold's Sand County Almanac (1949), or, Rachel Carson's more haunting Silent Spring (1962), it was not hard to conclude that the human impress on nature was poisonous.

For the most part, ignoring their complicity as consumers in the environmental despoliation they encountered, and yet increasingly better educated in the new science of ecology, this mid-1960s cohort made its demands felt. Those promoting wildland preservation found relief in the Wilderness Act (1964); those seeking expanded protection of stream flows championed the National Wild and Scenic Rivers Act (1968); for proponents of greater controls over public land management, the National Environmental Policy Act (1969) offered hopeful change; and to achieve a more salubrious environment, others applauded the Clean Air and Water Acts of the 1970s. Tallied together, these acts, and a set of related laws and legislation, perhaps most significantly the National Forest Management Act (1976), which compelled public access to land management decisions, meant one thing: The regulators were being regulated.

The Forest Service had never seemed so behind the times. Its leadership, trained to produce large quantities of timber, was ill prepared for the escalating public clamor that it embrace a different form of stewardship. Its claim of scientific expertise, once proudly worn like the shiny brass badges 


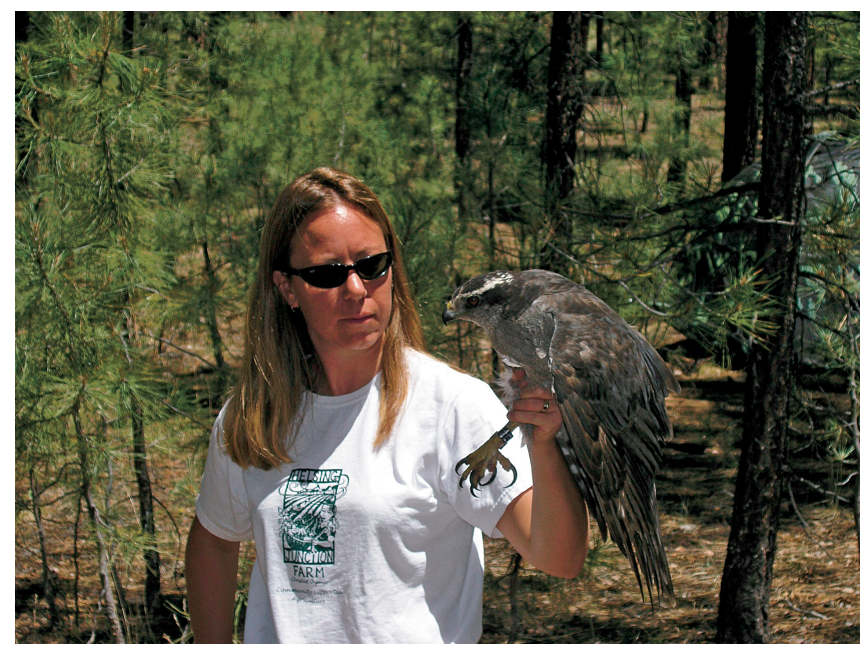

The Forest Service workforce changed dramatically in the 1990s. For example, the number of foresters declined by $43 \%$ between 1992 and 1999 while the number of general biologists and ecologists increased by more than 50\%. During the same period, the number of permanent rangeland conservationists dropped by $22 \%$ from 437 to 341 employees. Photo courtesy of Susan Salafsky.

on its green uniforms, seemed tarnished by its clumsy public relations ("Lassie" notwithstanding), by its misplaced confidence in its capacity to make the "right" decisions without public input, and by its circle-the-wagons approach even to constructive criticism. ${ }^{8}$

The agency's internal dynamics were in turmoil as well. New environmental laws required it to employ trained professionals in nontraditional fields, among them law, hydrology, wildlife biology, archaeology, even sociology. Some of those hired were women and minorities, whose increased presence diversified an agency that needed greater diversity. As with other aspects of American life, these transitions were turbulent, sparking lawsuits that alleged gender bias, racial discrimination, or reverse discrimination, further troubling agency culture. As it battled with itself and faced ongoing judicial review of its compliance with oft-contradictory environmental regulations, its late 20th century leaders coined the phrase "analysis paralysis" to describe its mired position. ${ }^{9}$ That by its own admission it was paralyzed, however, only reinforced its critics' belief that the Forest Service was incapable of change, stuck in a morass of its own making. One prominent analyst has pushed this argument farther, returning to Harold Ickes' original proposal and suggesting that it would make good sense if the Forest Service merged with the Bureau of Land Management and the National Park Service ${ }^{10}$; the agency's future, in short, might be limited; its second bicentennial not assured.

\section{Next Steps}

To imagine a more enduring future, the Forest Service must look to the past. Yet if history is the language we use to con- struct a bridge between then and now, what do these 4 historical crises suggest about tomorrow? What is the agency's legacy, however imperfectly conceived? Start with the first 4 principles Pinchot laid out in his "Rules for Public Service": Collectively they remind us that the Forest Service operates in a contested democratic arena that forces it to respond to new and shifting demands. To survive, it must be as resilient, adaptive, and as flexible as any of the species it stewards on the 192 million acres of National Forests and Grasslands. Because change is the only constant in our lives, a reality that holds true for the agency as well, the Forest Service's ability to evolve has been, and will remain, critical to its long-term sustainability. As Elizabeth Estill, now Deputy Chief for Programs and Legislation, said earlier in her career when defusing a particularly stressful situation: "This is not a crisis. It is business as normal" (J. W. Giltmier, personal communication, March 17, 2004). So it always has been, and always shall be.

The author is Professor of History at Trinity University, San Antonio, TX 78212-7200.

\section{References}

1. Miller, C. 2004. History's fiction. Journal of the West 43:23-24.

2. Steen, H. K. 2004. The U.S. forest service: A history. Centennial ed. Durham, NC, and Seattle, WA: Forest History Society and University of Washington Press.

3. Garland, H. 1910. Cavanagh, forest ranger; A romance of the mountain West. New York: Harper \& Brothers.

4. Greeley, W. B. 1920. Self-government in forestry. Journal of Forestry 18:106-109.

5. Miller, C. 2001. Gifford Pinchot and the making of modern environmentalism. Island Press.

6. Rothman, H. K. 1997. A regular ding-dong fight: the dynamics of Park Service-Forest Service controversy during the 1920s and 1930s. In: C. Miller [ed.]. American forests: Nature, culture, and politics. Lawrence, KS: University Press of Kansas. p. 114.

7. Clary, D. 1986. Timber and the Forest Service. Lawrence, KS: University Press of Kansas. p. 84-89.

8. HiRT, P. 1994. Conspiracy of optimism: Management of national forests since World War Two. Lincoln, NE: University of Nebraska Press.

9. Thomas, J. W. 2004. Jack Ward Thomas: The journals of a Forest Service chief. In: H. K. Steen [ed.]. Durham, NC, and Seattle, WA: Forest History Society and University of Washington Press.

10. FAirfaX, S. 2005. When an agency outlives its usefulness-a reflection. Journal of Forestry (in press). 